\title{
The Influence of the Movement in Shales on the Area of Oil Production
}

\author{
BY MICHARD A. CONKLING, * A. B., TULSA, OKLA. \\ (New York Meeting, February, 1917)
}

A sHate layer, buried beneath two or three thousand feet of strata, in some instances, will upon folding become thicker in the synclines and thinner on top of the anticlines.

This can be accounted for, in part, by the stretching on the crests of the fold and the compressing in the troughs; but this will by no means account for all of it, as is shown in the cxample herein set forth.

It is my firm belief that the rest of the thickness is due to flow. What causes the movement, however, does not concern us here, so long as there is movement, for this article purposes to show its effect upon the producing area of different sands.

It is the author's hope, in this way, to drop a hint or two that may be valuable to the oil geologist, in making estimates of future productions and values of oil properties. An example will be given from property in the famous Cushing Pool in northeastern Oklahoma, where the author has had occasion to make a detailed study before recommending some property to his company, and has then been able to watch the results of this work.

The author never mapped the surface structure in this pool, as this had been done by Frank Buttram when he was with the Oklahoma Geological Survey. We are using, therefore, a section of his map in this article for our surface contours. The main east dip comes farther east than this section shows.

From the 10-ft. contours in Fig. 1, it will be seen that the surface folding is very slight, but in the contour map of the Bartlesville sand (Fig. 2), which was the greatest producing sand, we see much more complex folding. It seems that the folding becomes greater with the depth. Folding may have started in Middle Pennsylvanian times and continued through the Upper Pennsylvanian which is found at the surface. This may, or may not, have been the cause of the increase of folding with depth. However, the fact that mostly concerns us is the interval of shale between the Bartlesville sand and the Tucker sand. The Tucker is the next productive sand below the Bartlesville. Not enough wells have been drilled to the Tucker sand to make a contour map of it, but

*Head Geologist, Roxana Petroleum Co. 
the figures beside the wells on Fig. 2 show the interval between the top of the Bartlesville and the top of the Tucker.

The entire area shown in Fig. 2, except the southeast corner, was productive in the Bartlesville sand. On the west edge of Section 10, a syncline will be observed. Water was encountered in this syncline at the bottom of the Bartlesville, but it did not rise high enough to ruin the wells for some time. The producing area of the Tucker sand is much smaller, however, as the surface of the sand dips more steeply

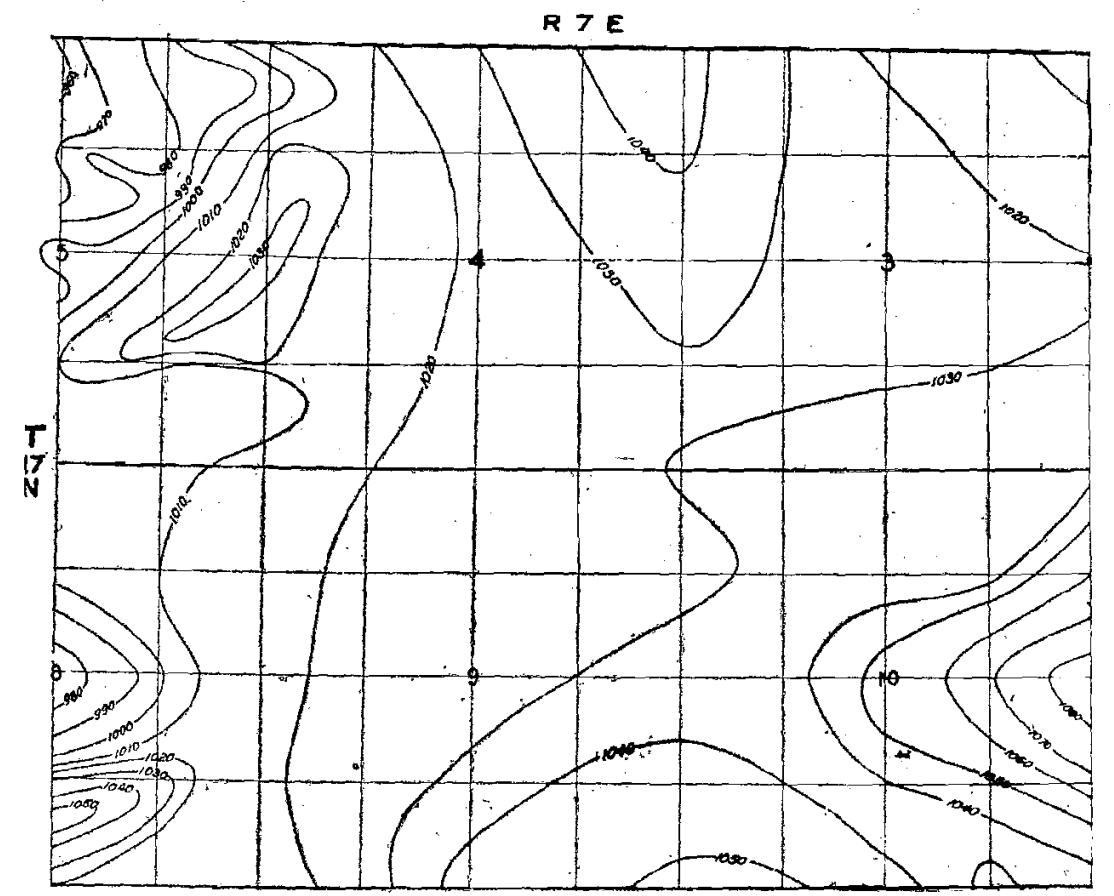

Fig. 1.-Segction of Coshina Figld. Contodrg on Pawhuska Limestone.

and goes more rapidly into water. It will be seen from the figures on the north line of Sections 8 and 9, and from the cross-section (Fig. 3) takén along that line, that the Tucker sand dips almost twice as steeply as the Bartlesville sand. The latter dips $70 \mathrm{ft}$. from Well No. 12, Maley Yarhola, to Well No. 4 of the Gypsy Oil Co., 1/4 mile east, while the former dips $123 \mathrm{ft}$. in the same distance. The difference is entirely due to the thickening of the shale interval between the two sands.

The producing area of the Tucker sand is, therefore, only a little over $1 / 4$ mile across. On top of this narrow anticline, however, was drilled the biggest producer of light oil known to the writer, namely, the No. 11 Jackson Barnett of the Gypsy Oil Co. of Oklahoma, which came in at $14,000 \mathrm{bbl}$. per day. 
After a few wells had been drilled to this sand, the exact limit of production was figured out, and our company is drilling accordingly.

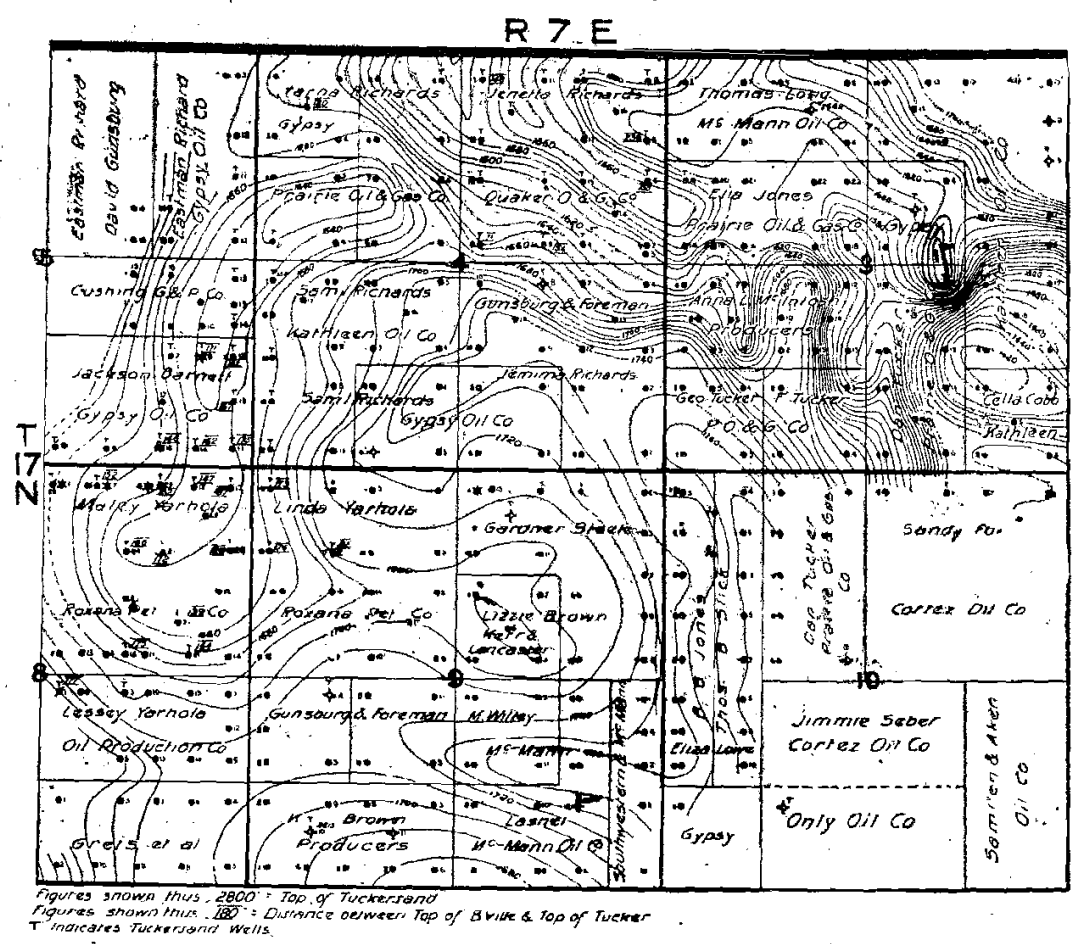

Fig. 2.-Section of Cushing Field. Contotrs on Bartlegville Sand.

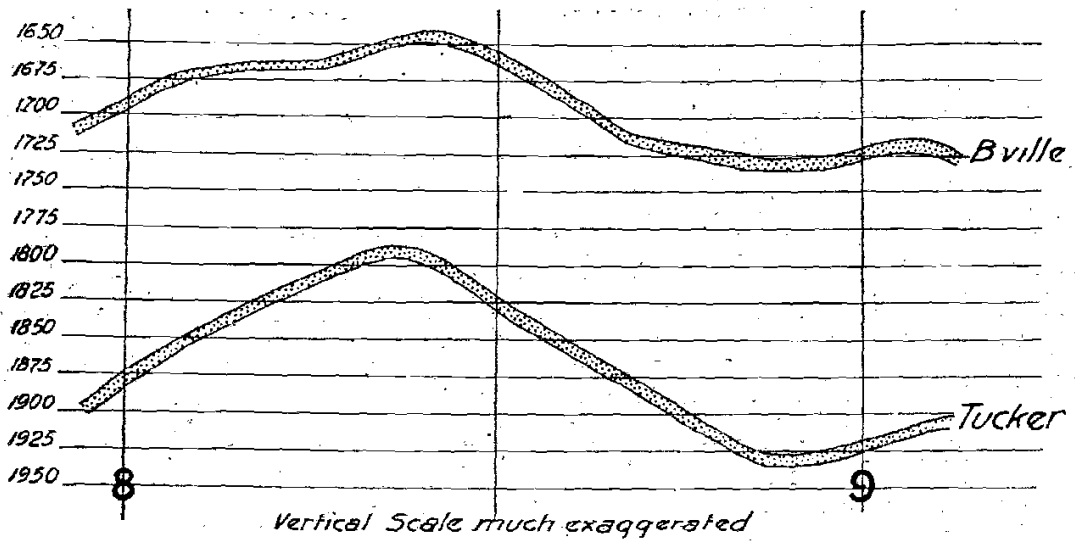

Fig. 3.-Section Showing Top of Bartumivilie and Tucker Sand.

By taking this thickening into account, millions of dollars were made for our company on purchasing of land. 
It will be seen that the same is true of the other domes on the maps. Of course these details cannot be told from the surface, but if one recognizes the conditions that these facts set forth, one need not go far astray when estimating the possible deeper-sand production in a developed field.

\section{Discussion}

D. W. OHern, Oklahoma, Okla. (communication to the Secretary*). -The author states: "A shale layer buried beneath 2,000 or $3,000 \mathrm{ft}$. of strata, in some instances, will upon folding become thicker in the synclines and thinner on top of the anticlines." In any series of folded strata there is a level of no strain. Provided the strata do not slip on each other, there would be above this level a thiokening of strata in the synclines and a thinning on the anticlines, as the author states, while the converse would obtain below this level. In order that the author's position be tenable, it would, in my judgment, be necessary to show that in the series of folded strata of the area under discussion the level of no strain was below the Bartlesville sand. In order even to approximate this level one should know both the thickness of strata removed by erosion since the time of folding and also the depth to which folding extends. Neither of these factors can be obtained.

There is considerable evidence in favor of the view that there is an unconformity below the Bartlesville sand in this region. Might it not therefore be that the variation in the thickness of the shale interval just below the Bartlesville sand is due to erosion? Personally, I am inclined to think this is a partial explanation in this particular case. On the other hand, the more rapid dip of the deeper strata seems to be the rule on structures in the Mid-Continent field. Mr. Conkling's observations on these sands are valuable; but one must wish for further data to substantiate the proposed explanation of their relations.

Dorser HAGER, Tulsa, Okla.--Recently we have been doing a little work along the same lines Mr. Conkling has outlined in his paper. I am not prepared to say that Mr. Conkling is not correct, but our results do not agree with his. I think it is a question of difference in correlation and interpretation of the well records. Our cross-section of the Cushing pool does not agree with that of Mr. Conkling and we find instead of the beds thickening in the syncline, there is a tendency to thicken on top of the anticline. We took the north dome of the Cushing field, and are now trying to get all the records. It will probably be another month before we have all the data complete, but our results at present do not agree with those of Mr. Conkling at all.

* Received Jan. 2, 1917. 
Rrchard A. Conkling (communication to the Secretary*).--Mr. Hager says that his results on the correlation of well logs in the north Cushing field are the opposite to those of the author. Can he, then, explain why the structural dip of the formations increases with depth, as Dr. Ohern, in his criticism, sets forth that it does, and as all who have worked in these fields will admit, if the shales thicken on the crest of the anticline, as he says they do? We are willing to agree with Dr. Ohern that there is some evidence of a slight unconformity below the Bartlesville sand and think that we can prove, from a specimen in our office, that this unconformity comes at the base of the Bartlesville sand in the south Cushing pool.

On the Ingalls dome, in the southeast corner of Township 19 North, Range 4 East, however, we get results the same as those given by the author on Cushing. The Ballard well in the center of the Northeast Quarter of Section 33 is just $10 \mathrm{ft}$. higher, structurally, according to the surface contour, than the Ringold well in the center of the Southwest Quarter of Section 34. The dip in the Bartlesville sand, between these wells, is $40 \mathrm{ft}$. and the dip on the top of the Mississippi lime is $75 \mathrm{ft}$. This also might be accounted for, partly by the unconformity, but the author used the interval between the top of the Oswego lime, which is about $420 \mathrm{ft}$. above the Bartlesville sand, and the oil horizon found in the lime in the Ballard well-just mentioned above-to find the depth at which the same oil should be found in a well in Section 5, Township 22 North, Range 3 East, 25 miles North. Using this interval below the Oswego in the former well, we predicted within $2 \mathrm{ft}$. where they would find the oil in the latter well. Of course, we know that it was accidental that we missed it only by $2 \mathrm{ft}$., but if there were much of an unconformity in this interval it would be more of an accident if we came within $100 \mathrm{ft}$. of the depth. Since it can be proven from most of the structures in this section that the dip continues to increase downward, below the Bartlesville at least, to the Mississippi lime, it does not seem necessary to the author to try to prove otherwise that the depth at which the shales will tend to thicken on top of a fold, has not been reached above the Tucker sand, if, as Dr. Ohern says, there is a certain place where such will be the ease. 